\title{
INVESTIGATION OF STINGING NETTLE (URTICA DIOICA L.) IN LITHUANIA
}

\section{PĒTİJUMS PAR LIELO NĀTRI (URTICA DIOICA L.) LIETUVĀ \\ Zofija JANKAUSKIENĖ}

Dr., senior scientist

\section{Elvyra GRUZDEVIENE்}

\author{
Dr., senior scientist \\ Upyte Experimental Station of the Lithuanian Research Centre for \\ Agriculture and Forest \\ e-mail: soja@upyte.lzi.lt, ph: +370 45 555413, fax: +370 45555573 \\ Linininkų 3, Upytè, Panevėžys district, LT-38 294, Lithuania
}

\begin{abstract}
Fiber nettle is a cultivated form of the wild nettle and could become a renewable recourse of natural fibres in Lithuania. The aim of research was to investigate propagation ability (shoot rooting) of stinging nettle, investigate influence of different crop density on plant biometrical indices, productivity. The investigation was carried out at the Upyte Research Station of LIA in 2008-2009. The shoots of stinging nettle were cut into segments, the top part of the stem and the segments of the stem were separated and planted in the filed separately. The crop of different density was established: $60 \times 60$ and $60 \times 100 \mathrm{~cm}$. The results of our investigation showed, that stinging nettle may be propagated in vegetative way, rooted under field conditions. The top parts of the stem shoved slightly better rooting results than the segments of the stem. Plants from the crop of 2nd year, $60 \times 60$, were grosser, more productive than that of the 1st year crop. Plants of the 1st year crop, 60x100, had more stems per plant than that of 1st year crop, 60x60, but amount of stems (units ha-1) was higher in the crop of 1st year crop, 60x60.
\end{abstract}

Keywords: Fibre, shoot rooting, stinging nettle, Urtica dioica L.

\section{Introduction}

Fiber nettle is a cultivated form of the wild nettle. By the way of selection fiber content was increased from about $5 \%$ in wild nettle plants to up to $17-18 \%$ of stalk dry matter in the cultivated species (4., 10). Fiber yield reportedly increases with plant density (10.).

Nowadays stinging nettle (Urtica diocia L.) is currently the subject of scientific interest and development in the following countries through Europe: Germany, Austria, Finland, UK, Italy, the Netherlands, and of course, in Lithuania. The plant is a promising candidate for sustainable production of natural fibre, particularly in Germany and central Europe (7.). Investigations in those countries showed that the nettle's dry stalks matter can vary from 2.3-9.7 t ha ${ }^{-1}$ (10.). The fiber yields (fiber yield = fiber content 
$\mathrm{x}$ dry matter yield) ranged from 335 to $411 \mathrm{~kg} \mathrm{ha}^{-1}$ in second growing year and from 743 to $1016 \mathrm{~kg} \mathrm{ha}^{-1}$ in third growing year (4.). When growing clones of high productivity (Austrian or German clones of stinging nettle), the yield between $6-8 \mathrm{t} \mathrm{ha}^{-1}$ of dry matter of straw with a raw fibre content of up to $25 \%$ (1.5-2.0 $\mathrm{t} \mathrm{ha}^{-1}$ ) could be produced (6.).

Investigation of stinging nettle in Italy in 2006-2007 showed that clones of German origin survived well, produced stalks the height of which was $1.71 \mathrm{~m}$, diameter $-5.2 \mathrm{~mm}$. stalks dry matter in average was $1542 \mathrm{~g} \mathrm{~m}^{-2}$, i.e. $15.4 \mathrm{t} \mathrm{ha}^{-1}$ (1.).

Propagation possibilities of stinging nettle are under dispute. Sowing of seeds with a drill may be the simplest operation, but because of the very low thousand kernel weight of the nettle seeds the soil of the field must be like garden and the depth of sowing $<1 \mathrm{~cm}$. The yang plants develop only slowly and their competition ability against weeds is low. Moreover, the uneven development of different genotypes in a stand after sowing could disturb the winning of fibres (7.). Sowing also leads to a reduction of fiber content: the fiber content of sown nettle plants was up to $2 \%$ lower than the fiber content of the mother plant which was cultivated under the same conditions and harvested at the same time (10.). So at the moment propagation of the nettles is possible only by cuttings. Vegetative propagation is simple but labour intensive, it can be done using conventional cabbage planting machinery (7.). The rooting ability is high, but expensive (11.). The best way to keep stabile characters of the clone is to cut the top part of the stinging nettle plant and root it the greenhouses, then transfer to the field (3., 4., 10.). Other sources suggest that division of stinging nettle plats succeeds at almost any time in the growing season, planting them straight out into their permanent positions (9.).

In the studied references detailed information about the shoot rooting of stinging nettle was not found, only in 2009 we found some information about investigations in Italy. Stinging nettle showed good altitude to be in vivo propagated by cuttings as well as throughout tissue culture. Both techniques results were suitable to be employed for production of plants for organic culture. In vivo propagation permits a large number of plants to be obtained in a short period, but requires large spaces and even using the mother plant grown in greenhouse, with seasonality influencing both the rate and the percentage of rooting. Small spaces and the independence from seasonality may be ensured using micro-propagation that can provide pure and healthy material (3.).

The first aim of our research was to investigate propagation ability (shoot rooting) of stinging nettle. The second - to establish field of stinging nettle crop to be able to investigate influence of different crop density on plant biometrical indices, to compare productivity of $1^{\text {st }}$ and $2^{\text {nd }}$ year crop. 


\section{Materials and methods}

The described investigation run to years: in 2008 the investigation of rooting of the stinging nettle was carried out (and the multiplying of the sowing material in the same case) and establishing of the crop at density $60 \times 60 \mathrm{~cm}$, and in 2009 - the establishment of the crop of different density (60x60 and $60 \times 100 \mathrm{~cm}$ ). The investigation was carried out at the Upyte Research Station of LIA (now it is Upyte Experimental Station of the Lithuanian Research Centre for Agriculture and Forest).

The investigation on rooting of the stinging nettle shoots in Lithuania was started in 2007 at the Upyte Research Station of LIA. The rooted shoots of stinging nettle were planted in one the fields of experimental crop rotation. Because of the reason, that stinging nettle is a perennial plant, in 2008 plants were transferred to the other field for long-lasting growing. Soil of new growing place for stinging nettle was kept free from weeds by the way of soil cultivation. In the autumn it was fertilised by manure and ploughed. In the spring it was cultivated and prepared for plant transportation. The plants, rooted in 2007, were planted in the field for investigation on the $6^{\text {th }}$ of May, 2008. Density of planted crop was 60 (between the plants in the row) x 60 (inter-row spacing) $\mathrm{cm}$. Plants were irrigated, full care of the plants was carried out (dead plants were replaced by alive ones, cultivation of inter-row spaces was carried out manually, observations on plant development and growing were conducted). None of pesticides (mineral fertilisers, herbicides, insecticides, fungicides or dessicants) were used for growing of stinging nettle.

In the studied references detailed information about the shoot rooting of stinging nettle was not found, thus we followed common rules for vegetative plant multiplying (12.).

The shoots of stinging nettle (top parts of the plant, cut at the $15 \mathrm{~cm}$ level above the ground) were sawn-off twice: on $2^{\text {nd }}$ of July, 2008 and on $12^{\text {th }}$ of August, 2008. For the transportation shoots were packed into plastic bag helter-skelter spraying them with small amount of water.

After transportation shoots were cut into segments, containing 3-4 axillar buttons and/or some leaves. The top part of the stem and the segments of the stem were separated and planted in the filed separately. The segments of stinging nettle for rooting were planted in the rows (inter-row spacing 60 or $100 \mathrm{~cm}$ ), the distance between plants - about $10 \mathrm{~cm}$. Later on (in 2009) successfully rooted plants were re-planted keeping distance of 60 $\mathrm{cm}$ between plants. In this way the crop of different density was established: $60 \times 60$ and $60 \times 100 \mathrm{~cm}$. Therefore, in 2009 the productivity of the $1^{\text {st }}$ year crop (established in 2009) and $2^{\text {nd }}$ year crop (established in 2008) as well as of different crop density (60x60 and 60x100 cm) of first year crop have been 
investigated.

In the established crop in 2008 before harvesting all the stems of stinging nettle plants ( 9 plants at crop density of $60 \times 60 \mathrm{~cm}$ ) in the area of $4 \mathrm{~m}^{2}(2 \mathrm{x} 2 \mathrm{~m}$ ) (in tree replications) were cut (leaving the stubble of $15 \mathrm{~cm}$ for sprouting of the plant) for the evaluation. Therefore, average data of 27 plants are presented in 2008.

In 2009 plots of the same area were cut for the evaluation in the crop of $2^{\text {nd }}$ year (established in 2008), 60x60 cm (abbreviation of the treatment $\mathbf{2}^{\text {nd }}$ year, 60x60); also in the crop of the $1^{\text {st }}$ year (established in 2009), $60 \times 60 \mathrm{~cm}$ (abbreviation of the treatment $-\mathbf{1}^{\text {st }}$ year, 60x60); also in crop of the $1^{\text {st }}$ year (established in 2009), $60 \times 100 \mathrm{~cm}$ (abbreviation of the treatment $-\mathbf{1}^{\text {st }}$ year, $\mathbf{6 0 x 1 0 0}$ ). Consequently, 9 plants from the plots where crop density is $60 \times 60 \mathrm{~cm}$ and 6 plants from the plots where crop density is $60 \times 100 \mathrm{~cm}$ were cut (triplicate) for evaluation.

The weight of green over-ground biomass (stems, leaves and inflorescences), its moisture content, absolutely dry biomass, amount of stems per plant, the length of the sawn-off stems, fibre content (with laboratory equipment LM-4) were evaluated. For calculation and statistical evaluation the statistical software developed in the Lithuanian Institute of Agriculture was used (8.).

In 2008 the weather conditions (Table 1) were favourable for the naturalization of transferred stinging nettle plants (sufficient amount of precipitation on I and II ten-day periods of May). Later on (III ten-day period of May and I of June) the luck of precipitation occurred, and stinging nettle was irrigated manually. The second part of June was rainy. Meteorological conditions were favourable for growing of stinging nettle. The shoots for rooting in July were irrigated by rain, as well as manually also. Similar conditions for shoot rooting were selected in August. Stinging nettle from $1^{\text {st }}$ year crop was harvested on $3^{\text {rd }}$ of September. Newly established (rooted in 2008) crop was not harvested.

In 2009 the beginning of the vegetation of stinging nettle was observed on the III ten-day period of April. For the establishment of different density crop weather was selected to be rainy and overcast (beginning of May), transferred stinging nettle also was irrigated manually. Later on (on I and II ten-day period of May) the luck of precipitation occurred. June and July had sufficient rainfall for stinging nettle. Plants were thriving well and flowering for a long time. Stinging nettle was harvested on $15^{\text {th }}$ of August. The rest part of stinging nettle plant (the stubble of $15 \mathrm{~cm}$ ) shot again after sawingoff successfully. 
Table 1

Mean weather temperature and precipitation during stinging nettle rooting and growing season Upyte், 2008-2009

\begin{tabular}{|c|c|c|c|c|c|c|c|}
\hline \multirow[b]{2}{*}{ Month } & \multirow{2}{*}{$\begin{array}{c}\text { Ten-day } \\
\text { period }\end{array}$} & \multicolumn{3}{|c|}{ Mean weather temperature, ${ }^{\circ} \mathrm{C}$} & \multicolumn{3}{|c|}{ Rainfall, mm } \\
\hline & & 2008 & 2009 & $\begin{array}{l}\text { Long-term } \\
\text { average }\end{array}$ & 2008 & 2009 & $\begin{array}{c}\text { Long-term } \\
\text { average }\end{array}$ \\
\hline \multirow[t]{4}{*}{ May } & $\mathrm{I}$ & 8.5 & 12.1 & 11.0 & 16.1 & 10 & 16.0 \\
\hline & II & 11.8 & 15.3 & 12.6 & 12.5 & 2.1 & 16.0 \\
\hline & III & 13.4 & 17.6 & 13.5 & 0.1 & 10.5 & 18.0 \\
\hline & Aver./total & 111.2 & $\overline{15.0}$ & $\overline{12.4}$ & 28.7 & 22.6 & $\overline{50.0}$ \\
\hline \multirow[t]{4}{*}{ June } & $\mathrm{I}$ & 17.0 & 16.3 & 14.4 & 0 & 57 & 22.0 \\
\hline & II & 15.0 & 17.3 & 15.3 & 32 & 21 & 23.0 \\
\hline & III & 15.4 & 21.3 & 16.2 & 56 & 7.5 & 24.0 \\
\hline & Aver./total & $\mathbf{1 5 . 8}$ & 18.3 & 15.3 & 88 & 85.5 & 69.0 \\
\hline \multirow[t]{4}{*}{ July } & $\overline{\mathrm{II}}$ & 16.8 & 21.9 & 17.2 & 9.5 & 37.5 & 25.0 \\
\hline & II & 17.9 & 20.5 & 18.0 & 41 & 55 & 25.0 \\
\hline & III & 17.4 & 18.5 & 18.0 & 15.5 & 30 & 26.0 \\
\hline & Aver./total & 17.4 & 20.3 & 17.7 & 66.0 & 122.5 & 76.0 \\
\hline \multirow[t]{4}{*}{ August } & $\mathrm{I}$ & 17.1 & 17.6 & 17.2 & 47.5 & 0.0 & 28.0 \\
\hline & II & 19.9 & 17.6 & 16.1 & 44.5 & 28.5 & 29.0 \\
\hline & III & 16.1 & 15.8 & 15.0 & 21.1 & 45.0 & 28.0 \\
\hline & Aver./total & 17.7 & 177.0 & $\overline{16.1}$ & 113.1 & 73.5 & 85.0 \\
\hline \multirow[t]{4}{*}{ September } & $\overline{I I}$ & 16.9 & 16.6 & - & 4.5 & 17.0 & - \\
\hline & II & 8.3 & 14.0 & - & 5.0 & 21.0 & - \\
\hline & III & 10.7 & 15.0 & - & 2.0 & 10.0 & - \\
\hline & Aver./total & 12.0 & 15.2 & - & 11.5 & 48.0 & - \\
\hline \multirow[t]{4}{*}{ October } & $\mathrm{I}$ & 8.1 & 7.1 & - & 10.3 & 38.0 & - \\
\hline & II & 9.9 & 2.8 & - & 44.6 & 36.0 & - \\
\hline & III & 7.9 & 5.4 & - & 31.5 & 12.0 & - \\
\hline & Aver./total & 8.6 & 5.1 & - & 86.4 & 86.0 & - \\
\hline
\end{tabular}

Thermal and irrigation conditions during the growing season could be described by one of the most informative agrometeorological indicators G. Selianinov's hydrothermal coefficient (1.):

$$
H T K=\frac{\Sigma p}{0.1 \Sigma t}
$$

where:

$\Sigma \mathrm{p}$ - total precipitation $(\mathrm{mm})$ sum during the given period, the temperature of which is above $10^{\circ} \mathrm{C}$;

$\Sigma \mathrm{t}-$ total sum of active temperatures $\left({ }^{\circ} \mathrm{C}\right)$ of the same period. 
If HTK > 1.6 - excessive irrigation, HTK = 1...1.5 - optimal irrigation, $\mathrm{HTK}=0.9 \ldots 0.8-$ weak drought, $\mathrm{HTK}=0.7 \ldots 0.6$ - moderate drought, $\mathrm{HTK}=$ 0.5...0.4 - strong drought, HTK $<0.4$ - very strong drought.

According to the data presented in Figure 1, it would be fair to say that in 2008 too dry weather conditions were on the III ten-day period of May, I ten-day period of June (very strong drought), I ten-day period of July and over all September. In 2009 too dry weather was in May, on III ten-day period of June, I ten-day period of August, III ten-day period of September.

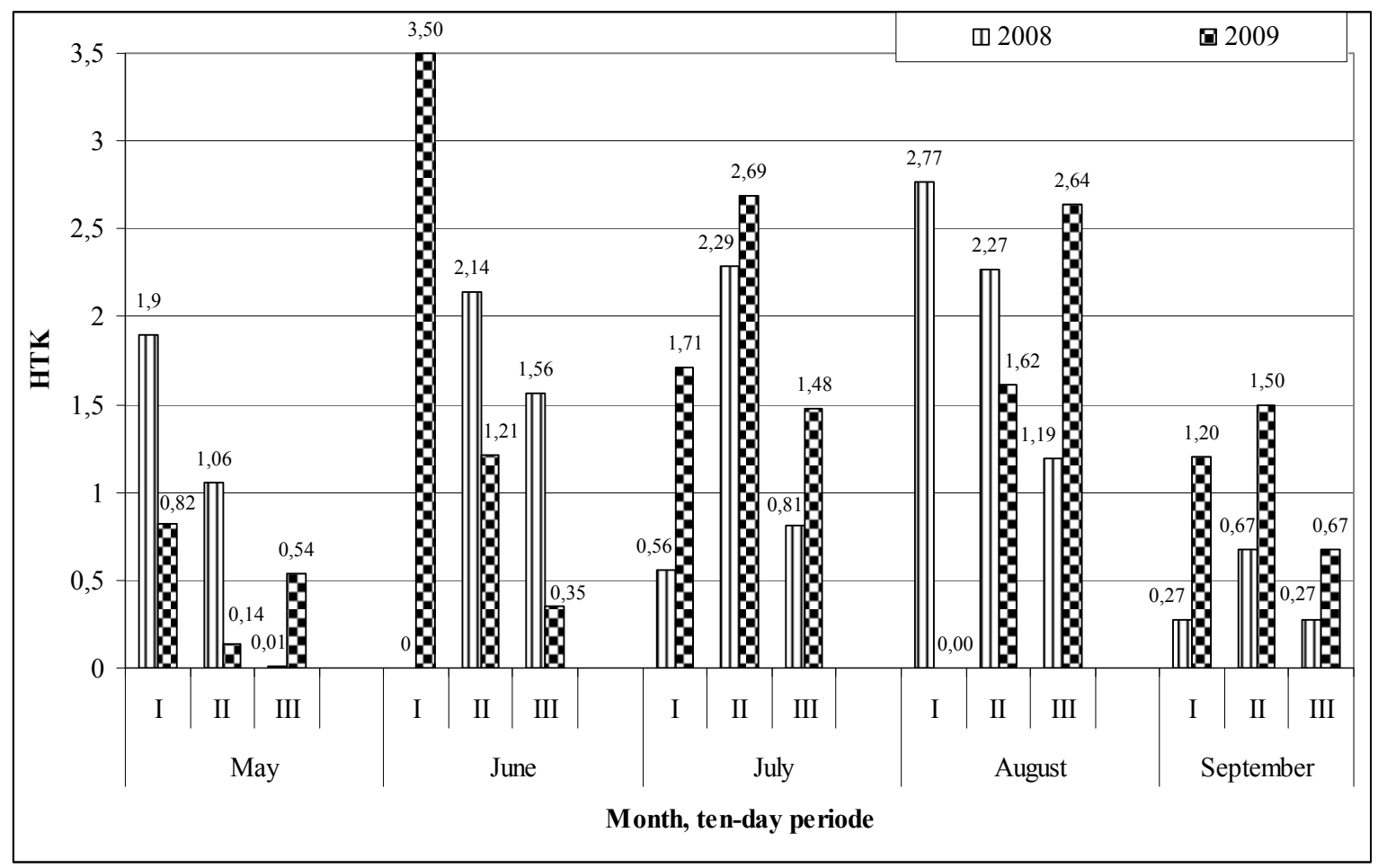

Figure 1. Hydrothermal coefficient during the growing period of stinging nettle. Upytè, 2008-2009

\section{Results and discussion}

The shoots of stinging nettle planted in July were sprouting well, growing shoots and roots, so the naturalization (successful rooting) of stinging nettle shoots was evaluated 3 weeks after planting, on the $24^{\text {th }}$ of June. The results (Table 2) showed that $52 \%$ of the stem segments and $73 \%$ of top parts of the stem rooted successfully, but the results varied in the different places of rooting.

The investigation of rooting was done again in August. Now cut segments and top parts of the stem were planted with the inter-row spacing of $1 \mathrm{~m}$. Some time after planting shoots look like dead, sprouting, shooting and rooting run very slowly, so the results were fixed only 1.5 month after planting. Rooting results are presented in Table 3 . We found that $63 \%$ of the stem segments and $86 \%$ of top parts of the stem rooted successfully, but 
the results varied in the different places of rooting. Also we should point out, that plants, rooted in August, look more weak than that, rooted in July, and not only in 2008, but also in 2009.

Table 2

The results of rooting of stinging nettle shoots in July Upyte, 2008

\begin{tabular}{|l|c|c|c|}
\hline \multicolumn{1}{|c|}{ Row, treatment } & $\begin{array}{c}\text { Planted } \\
\text { 02-07-2008 }\end{array}$ & $\begin{array}{c}\text { Rooted } \\
\text { 24-07-2008 }\end{array}$ & Rooting, in \% \\
\hline Row 1, segments of stem & 410 & 227 & 55.37 \\
\hline Row 2, segments of stem & 411 & 239 & 58.15 \\
\hline Row 3, segments of stem & 404 & 258 & 63.86 \\
\hline Row 4, the tops of stem & 337 & 271 & 80.42 \\
\hline Row 5, segments of stem & 399 & 218 & 54.64 \\
\hline Row 6, segments of stem & 428 & 215 & 50.23 \\
\hline Row 7, segments of stem & 398 & 151 & 37.94 \\
\hline Row 8, the tops of stem & 310 & 219 & 70.65 \\
\hline Row 9, segments of stem & 401 & 164 & 40.90 \\
\hline Row 10, segments of stem & 423 & 227 & 53.66 \\
\hline Row 11, segments of stem & 240 & 108 & 45.00 \\
\hline Row 11, the tops of stem & 115 & 70 & 60.87 \\
\hline Row 12, segments of stem & 122 & 76 & 62.30 \\
\hline Total/average of segments & $\mathbf{3 6 3 6}$ & $\mathbf{1 8 8 3}$ & $\mathbf{5 1 . 7 9}$ \\
\hline Total/average of the tops & $\mathbf{7 6 2}$ & $\mathbf{5 6 0}$ & $\mathbf{7 3 . 4 9}$ \\
\hline
\end{tabular}

Contrary to the rooting results in 2007 (5.), in 2008 the best results for rooting showed top parts of the stem.

Table 3

The results of rooting of stinging nettle shoots in August Upyte, 2008

\begin{tabular}{|c|c|c|c|}
\hline Row, treatment & $\begin{array}{c}\text { Planted } \\
12-08-2008\end{array}$ & $\begin{array}{c}\text { Rooted } \\
30-09-2008\end{array}$ & Rooting, in \% \\
\hline Row 0 (not full), segments of stem & 189 & 177 & 93.65 \\
\hline Row 1 , segments of stem & 373 & 221 & 59.25 \\
\hline Row 2, segments of stem & 447 & 253 & 56.60 \\
\hline Row 3 , segments of stem & 443 & 197 & 44.47 \\
\hline Row 4, segments of stem & 432 & 246 & 56.94 \\
\hline Row 5 , segments of stem & 421 & 240 & 57.01 \\
\hline Row 6, segments of stem & 446 & 410 & 91.93 \\
\hline Row 7, the tops of stem & 389 & 380 & 97.69 \\
\hline Row 8 , the tops of stem & 358 & 345 & 96.37 \\
\hline Row 9 (not full), the tops of stem & 254 & 138 & 54.33 \\
\hline Total/average of segments & 2751 & 1744 & 63.40 \\
\hline Total/average of the tops & 1001 & 863 & 86.21 \\
\hline
\end{tabular}

The length of the stems was measured just after cutting. Generally, the stems were single, but some part of them had branches. In 2008 in the crop 
of the $1^{\text {st }}$ year, crop density $60 \times 60 \mathrm{~cm}$, the amount of stems per 1 plant varied from 15 to 79 . The average length of sawn-off stems was $1.40 \mathrm{~m}$ (without the height of the stubble left in the field), it varied from 0.09 to $1.94 \mathrm{~m}$. The average weight of green over-ground mass per plant was close to $1 \mathrm{~kg}$, therefore, it is possible to harvest $22.6 \mathrm{t}$ of green or more than $10 \mathrm{t}$ of absolutely dry over-ground mass per hectare (Table 4 ).

Table 4

The biometrical indices of the $1^{\text {st }}$ year stinging nettle crop (established in 2008), $60 \times 60 \mathrm{~cm}$ (abbreviation of the treatment $-1^{\text {st }}$ year, 60x60)

Upyte, 2008

\begin{tabular}{|l|c|}
\hline \multicolumn{1}{|c|}{ The biometrical indices } & Mean \\
\hline Amount of stems, units per plant & 42.8 \\
\hline Amount of stems, units ha ${ }^{-1}$ & 963333 \\
\hline The average length of sawn-off stem, $\mathrm{m}$ & 1.40 \\
\hline The average total plant height (taking in mind the height of stubble), $\mathrm{m}$ & 1.55 \\
\hline Total length of the sawn-off stems, $\mathrm{m} \mathrm{4} \mathrm{m}^{-2}$ & 562.95 \\
\hline Total length of the sawn-off stems, $\mathrm{m} \mathrm{ha}^{-1}$ & 1407383 \\
\hline The average weight of green over-ground mass, $\mathrm{kg}^{-}$per plant & 1.01 \\
\hline The average weight of green over-ground mass, $\mathrm{kg} \mathrm{ha}^{-1}$ & 22614 \\
\hline Moisture content in the green biomass, \% & 52.3 \\
\hline The average weight of absolutely dry over-ground mass, $\mathrm{kg} \mathrm{per} \mathrm{plant}^{-1}$ & 0.48 \\
\hline The average weight of absolutely dry over-ground mass, $\mathrm{kg} \mathrm{ha}^{-1}$ & 10787 \\
\hline
\end{tabular}

Evaluated and calculated data from 2009 are presented in the Table 5. In 2009 in the crop of the $2^{\text {nd }}$ year, 60x60, plants were grosser than that of the $1^{\text {st }}$ year crop. The amount of stems (units per plant) varied from 12 to 68. The highest average amount of stems (42.9 units per plant) was found to be in the crop of $2^{\text {nd }}$ year, $60 \times 60$. Plants of the $1^{\text {st }}$ year crop, $60 \times 100$, had more stems per plant (32.9) than that of $1^{\text {st }}$ year crop, 60x60 (25.4), but the differences between treatments were not significant. Nevertheless, amount of stems (units ha ${ }^{-1}$ ) was significantly higher in the crop of $2^{\text {nd }}$ year, 60x60, and significantly lower in the crop of $1^{\text {st }}$ year, 60x100. In 2009 the stems of stinging nettle were less branched than that in 2008.

The length of sawn-off stems varied from 0.17 to $2.34 \mathrm{~m}$, but the average length of sawn-off stem was very similar in all treatments (1.66-1.68 $\mathrm{m}$ ). The highest sawn-off plants (not in the record plots, where measurement was carried out) reached the height of 2.79-2.81 m.

Total length of the sawn-off stems in 1 ha was significantly higher in the crop of $2^{\text {nd }}$ year, $60 \times 60$, it reached 1.5 million meters. In the crop of $1^{\text {st }}$ year, $60 \times 100$, the total length of the sawn-off stems in 1 ha was by twice less - 0.799 million meters. 
The average weight of green over-ground mass (kg per plant) in all treatments was higher than that in 2008. In 2009 the crop of $1^{\text {st }}$ year, 60x60, produced $1.26 \mathrm{~kg}$ per plant, and in 2008 the crop of $1^{\text {st }}$ year, 60x60, produced $1.0 \mathrm{~kg}$ per plant. In 2009 the crop of $2^{\text {nd }}$ year, $60 \times 60$, produced highest amount of green over-ground mass (1.70 kg per plant), but the differences between treatments weren't significant. The same tendencies could be noted in the average weight of green over-ground mass $\mathrm{kg} \mathrm{ha}^{-1}$. Calculated weight of green over-ground (stalks, leaves, inflorescences) mass was close to $38 \mathrm{t} \mathrm{ha}^{-1}$ from the crop of $2^{\text {nd }}$ year, $60 \mathrm{x} 60$, and more than $20 \mathrm{t}$ $\mathrm{ha}^{-1}$ from the crop of $1^{\text {st }}$ year. Although the plants of $1^{\text {st }}$ year crop, $60 \times 100$, produced higher amount of green biomass per plant than that of the $1^{\text {st }}$ year crop, $60 \times 100$, amount of green biomass per hectare was higher in the crop of $1^{\text {st }}$ year, $60 \times 60$.

Table 5

The biometrical indices of the $2^{\mathrm{dn}}$ year stinging nettle crop (established in 2008), $60 \times 60 \mathrm{~cm}$ (abbreviation of the treatment $-2^{\text {nd }}$ year, 60x60), of the $1^{\text {st }}$ year crop (established in 2009), 60x60 cm (abbreviation of the treatment $1^{\text {st }}$ year, 60x60), of the $1^{\text {st }}$ year crop (established in 2009), $60 \times 100 \mathrm{~cm}$ (abbreviation of the treatment $-1^{\text {st }}$ year, 60x100).

Upyte, 2009

\begin{tabular}{|c|c|c|c|c|}
\hline The biometrical indices & $\begin{array}{l}2^{\text {nd }} \text { year, } \\
60 \times 60\end{array}$ & $\begin{array}{l}1^{\text {st }} \text { year, } \\
60 \times 60\end{array}$ & $\begin{array}{l}1^{\text {st }} \text { year, } \\
60 \times 100\end{array}$ & Mean \\
\hline $\begin{array}{l}\text { Amount of stems, units per plant }\left(\mathrm{LSD}_{05}\right. \\
\text { 9.19) }\end{array}$ & 42.9 & 25.4 & 32.9 & 33.7 \\
\hline Amount of stems, units ha ${ }^{-1}\left(\mathrm{LSD}_{05} 179361\right)$ & 965833 & 571667 & 493333 & 676944 \\
\hline $\begin{array}{l}\text { The average length of sawn-off stem, } \mathrm{m} \\
\left(\mathrm{LSD}_{05} 0.351 \text { ) }\right.\end{array}$ & 1.66 & 1.68 & 1.67 & 1.67 \\
\hline $\begin{array}{l}\text { The average total plant height (taking in } \\
\text { mind the height of stubble), } \mathrm{m}\left(\mathrm{LSD}_{05} 0.220\right)\end{array}$ & 1.81 & 1.83 & 1.82 & 1.82 \\
\hline $\begin{array}{l}\text { Total length of the sawn-off stems, } \mathrm{m} 4 \mathrm{~m}^{-2} \\
\left(\mathrm{LSD}_{05} 152.040\right)\end{array}$ & 608.78 & 358.74 & 319.73 & 437.19 \\
\hline $\begin{array}{l}\text { Total length of the sawn-off stems, } \mathrm{m} \mathrm{ha}^{-1} \\
\left(\mathrm{LSD}_{05} 380100\right)\end{array}$ & 1521950 & 957686 & 799325 & 1092987 \\
\hline $\begin{array}{l}\text { The average weight of green over-ground } \\
\text { mass, kg per plant ( } \mathrm{LSD}_{05} 0.652 \text { ) }\end{array}$ & 1.70 & 1.26 & 1.37 & 1.44 \\
\hline $\begin{array}{l}\text { The average weight of green over-ground } \\
\text { mass, } \mathrm{kg} \mathrm{ha}^{-1}\left(\mathrm{LSD}_{05} 13 \text { 942) }\right.\end{array}$ & 38163 & 28337 & 20577 & 29026 \\
\hline $\begin{array}{l}\text { The average weight of absolutely dry over- } \\
\left.\text { ground mass, kg per plant (LSD }{ }_{05} 0.252\right)\end{array}$ & 0.65 & 0.49 & 0.53 & 0.56 \\
\hline $\begin{array}{l}\text { The average weight of absolutely dry over- } \\
\text { ground mass, } \mathrm{kg} \mathrm{ha}^{-1}\left(\mathrm{LSD}_{05} 5376\right)\end{array}$ & 14716 & 10927 & 7934 & 11192 \\
\hline
\end{tabular}

Moisture content in the green biomass was established (61.44 \%), and yield of absolutely dry biomass was calculated. Again the highest 
productivity $\left(14.7 \mathrm{t} \mathrm{ha}^{-1}\right)$ shoved the crop of $2^{\text {nd }}$ year, $60 \mathrm{x} 60$, less productive $\left(7.9 \mathrm{t} \mathrm{ha}^{-1}\right)$ were plants from the crop of $1^{\text {st }}$ year, $60 \times 100$.

The results obtained in 2008-2009 showed, that stinging nettle (fibre type) may grow in Lithuania and produce about 800-900 $\mathrm{kg} \mathrm{ha}^{-1}$ (or even more in following years) of scutched fibre with raw fibre content close to $18 \%$.

\section{Conclusions}

1. The results of our investigation showed, that stinging nettle may be propagated in vegetative way, rooted under field conditions. The top parts of the stem shoved slightly better rooting results than the segments of the stem. Although better rooting results were obtained when propagating stinging nettle in the middle of August but plants, rooted in August, look more weak than that, rooted in July, and not only in 2008, but also in 2009.

2. Plants from the crop of $2^{\text {nd }}$ year, $60 \times 60$, were grosser, more productive than that of the $1^{\text {st }}$ year crop.

3. Plants of the $1^{\text {st }}$ year crop, $60 \times 100$, had more stems per plant than that of $1^{\text {st }}$ year crop, 60x60, but amount of stems (units ha-1) was higher in the crop of $1^{\text {st }}$ year crop, $60 \times 60$.

4. The average length of sawn-off stems was very similar in all treatments $(1.66-1.68 \mathrm{~m})$. The highest sawn-off plants reached the height of 2.79$2.81 \mathrm{~m}$.

5. The weight of green over-ground (stalks, leaves, inflorescences) mass was close to $38 \mathrm{t} \mathrm{ha}{ }^{-1}$ from the crop of $2^{\text {nd }}$ year, $60 \times 60$, and more than $20 \mathrm{t} \mathrm{ha}{ }^{-1}$ from the crop of $1^{\text {st }}$ year. Although the plants of $1^{\text {st }}$ year crop, $60 \times 100$, produced higher amount of green biomass per plant than that of the $1^{\text {st }}$ year crop, $60 \times 100$, amount of green biomass per hectare was higher in the crop of $1^{\text {st }}$ year, $60 \times 60$.

\section{Bibliography}

1. Bacci L., Baronti S., Crisci A., Predieri A., Virgilio N. di, Romani A., Pirelli P. (2007). The cultivation of fibre nettle in Italy: first results. Innovative technologies for comfort: Proceedings of the 4th global workshop (general consultation) of the FAO/ESCORENA European cooperative research network on flax and other bast plants, 7-10 October, Arad, Romania. - Bucuresti: Certex, p. 249.

2. Bukantis A. (1998). Agroklimatinių resursų dinamika ir augalininkystès plètros perspektyvos Lietuvoje. Augalininkystes ir bitininkystes dabartis ir ateitis: moksliniu straipsnių rinkinys, Kaunas-Akademija, p. 17-23.

3. Gatti E., Di Virgilio N., Baronti S., Bacci L. (2008). Development of propagation methods for organic production of fibre (Urtica dioica L.). Fibre foundations transportation, clothing \& shelter in the bioeconomy: international conference on flax \& other bast plants. July 21-23, 2008, Saskatoon, Saskatchewan, Canada, p. 445. 
4. Hartll A., Vogl Ch. R. (2002). Dry matter and fiber yields, and the fiber characteristics of five nettle clones (Urtica dioica L.) organically grown in Austria for potential textile use. American Journal of Alternative Agriculture, Volume 17, Number 4, p. 195-200.

5. Jankauskienė Z., Gruzdevienė E. (2008). Stinging nettle (Urtica dioica L.) - an alternative fibre plant. Opportunities and Challenges of National Economic Development: proceedings of the International conference, April 17, 2008. Rezekne, p.175-182.

6. Nebel K., Kokhan A., Selcuk R., Pichert T. (2002). Textiles from fibre nettles. Production, Processing and Use of Natural Fibres. Potsdam-Bornim, p. 77-78.

7. Nettle, stinging (2002). Retrieved from http://www.ienica.net/crops/nettle.htm, accessed on 11-02-2010.

8. Tarakanovas P., Raudonius S. (2003). Agronominių tyrimų duomenų statistinè analizė taikant kompiuterines programas Anova, Stat, Split-Plot iš paketo SELEKCIJA ir IRRISTAT. Akademija, 58 p.

9. Urtica dioica-L. - Stinging nettle. Retrieved from http://www.pfaf.org/database/plants.php?Urtica+dioica, accessed on 11-02-2010

10. Vogl Ch. R., Hartll A. (2003). Production and processing of organically grown fiber nettle (Urtica dioica L.) and its potential use in the natural textile industry: A review. American Journal of Alternative Agriculture, Volume 18, Number 3, p. 119128.

11. Wurl G., Graft T., Vetter A., Biertumfel A. (2002). 10 years agrotechnical trials to fibre nettle (Urtica dioica L.) in Thuringia. Production, Processing and Use of Natural Fibres. Potsdam-Bornim, p. 95-96.

12. Поликарпова Ф.Я. (1990). Размножение плодовых и ягодных культур зелеными черенками. Москва: В0 Агропромиздат, 96 с.

\section{Summary}

Fiber nettle is a cultivated form of the wild nettle and could become a renewable recourse of natural fibres in Lithuania. The aim of research was to investigate propagation ability (shoot rooting) of stinging nettle, investigate influence of different crop density on plant biometrical indices, productivity. The investigation was carried out at the Upyte Research Station of LIA in 2008-2009. The shoots of stinging nettle were cut into segments, the top part of the stem and the segments of the stem were separated and planted in the filed separately. The crop of different density was established: 60x60 and $60 \times 100 \mathrm{~cm}$. The results of our investigation showed, that stinging nettle may be propagated in vegetative way, rooted under field conditions. The top parts of the stem shoved slightly better rooting results than the segments of the stem. Plants from the crop of $2^{\text {nd }}$ year, $60 \times 60$, were grosser, more productive than that of the $1^{\text {st }}$ year crop. Plants of the $1^{\text {st }}$ year crop, $60 \times 100$, had more stems per plant than that of $1^{\text {st }}$ year crop, $60 \mathrm{x} 60$, but amount of stems (units ha-1) was higher in the crop of $1^{\text {st }}$ year crop, 60x60. The average length of sawn-off stems was very similar in all treatments $(1.66-1.68 \mathrm{~m})$. The highest sawn-off plants reached the height of $2.79-2.81 \mathrm{~m}$. The weight of green over-ground (stalks, leaves, inflorescences) mass was close to $38 \mathrm{t} \mathrm{ha}{ }^{-1}$ from the crop of $2^{\text {nd }}$ year, $60 \times 60$, and more than $20 \mathrm{t} \mathrm{ha}^{-1}$ from the crop of $1^{\text {st }}$ year. Although the plants of $1^{\text {st }}$ year crop, $60 \times 100$, produced higher amount of green biomass per plant than that of the $1^{\text {st }}$ year crop, $60 \times 100$, amount of green biomass per hectare was higher in the crop of $1^{\text {st }}$ year, $60 \times 60$. 